\title{
Emerging from a Turbulent Marketplace
}

\author{
Arthur F. Ryan \\ Prudential Financial, Inc., 751 Broad Street, 16th Floor, Newark, NJ 07102, U.S.A. \\ E-mails: arthur.ryan@prudential.com, greg.loder@prudential.com
}

Coming out of the perfect storm of a bear market in equities, poor credit markets, and low interest rates, the U.S. insurance industry faced a number of new realities based on changing consumer demand and expectations. Consumers wanted new guarantees in their investments, choice and flexibility in distribution, and simplicity in their financial products. The baby boomers echo this new consumer demand through their desire for retirement security. The life insurance industry is well positioned to deliver to this population. No other financial services industry can help individuals accumulate wealth, protect its value, convert the wealth into lifetime income, and transfer it to future generations like the life insurance industry can. There are risks ahead for the U.S. life industry; however, it can take advantage of opportunities in the future if it can continue to put consumer needs first.

The Geneva Papers (2007) 32, 58-61. doi:10.1057/palgrave.gpp.2510113

Keywords: U.S. life insurance industry; consumer demand; product guarantees; living benefits; baby boomers; retirement security

The life insurance industry in the U.S. faced difficult times in the first few years of the current decade. Some called it a perfect storm because a number of elements hit all at the same time. A bear market in equities, poor credit markets, and the lowest interest rates in 40 years put a great deal of pressure on companies' ratings and capital position. The insurance industry was living off its investment returns instead of sales, while demand for life products was leveling off.

Due to the extreme volatility in equity markets, sales of variable life and variable universal life fell by 36 per cent from year 2000 levels. In addition, the entire financial services industry was facing new regulatory scrutiny after some high profile debacles and corporate governance scandals.

The life insurance industry itself faced a number of new challenges with increased focus on commissions, fees, and questions concerning conflicts of interest. Finally, the life industry lost a debate in Congress to give annuities the same tax break as capital gains and dividends.

Not surprisingly, when the storm subsided, the U.S. life industry found that consumer demand and expectations had changed. The stock market fluctuations drove consumer demand to products with less downside risk. Near retirees became concerned about protecting nest eggs. Living benefits appeared and in many cases became as important as death benefits. Companies that focused on asset accumulation now needed to help individuals maintain financial security in retirement.

Consumers wanted better advice, more convenience in buying, and more selection. They wanted guarantees that what they bought would increase in value, or, at the very least, would not lose value. In many instances, consumers 
also wanted customization in their products. Flexibility through riders and other features became very important.

Interestingly, this new consumer satisfaction is not necessarily derived from the convenience of a one-stop shop. Instead, it comes from finding the best in class product that fits specific needs, from a trusted company, and the ability to get it when you want it, however you want it.

Some industries were faced with this challenge before ours and have figured out how to deal with this change. In the computer industry, Dell and now Hewlett-Packard allow individuals to order customized computers online. Music lovers can take an entire music collection anywhere with the Apple iPod. And, consumers can get coffee made to order at almost every street corner through Starbucks.

The challenge of making it "my way" is not a whole lot different for the financial services industry. First, it means figuring how to reach the customer. For many companies, this means building multiple access points - propriety distribution through agents, third-party distribution through brokers and banks, and online distribution through the Internet. These days even our captive distribution, with its open architecture, is acting like an independent channel.

Distribution choice is just one part of the equation. Next, companies need to understand what the consumer wants, or at least what the consumer wants to choose from. That means greater product flexibility. Consumers want customization of their products to meet specific needs. Today, consumers are more aware of their life cycle and the need to change their portfolios accordingly.

Customer concerns have changed. Longer life expectations have transformed consumer fears of dying too young to concerns about outliving their assets. Near retirees and retirees, after losses in the equity markets, are now concerned about their nest eggs. They are looking for solid guarantees - guarantees that their money will be there when they need it.

The development of guarantees and living benefits is part of the reality of new consumer needs. Variable annuities are a good example of this. Decreasing equity markets drove down variable annuity sales. Now the markets are stronger as are variable annuity sales. But, there is one major difference. Variable annuity products now have guarantees and living benefits.

Living benefits usually fall into three categories dealing with guaranteed minimum income, accumulation, or withdrawal benefits. Companies are getting innovative with these areas and are offering new features, such as giving the customer choice at the point of distribution, and not locking them in on purchase. Some are also adding immediate withdrawals.

Overall sales of variable annuities rebounded, reaching $\$ 126$ billion in 2005 . That is the second highest total to the 2000 record of $\$ 137$ billion. Interestingly, more than 85 per cent of all VA contracts sold offer one or more living benefit guarantees.

Industry responses to date are not the end of the story. In fact, they are only the beginning. Product innovation needs to continue. It is not only protecting nest eggs, but also health care costs, and comfort in retirement. Consumers are worried. This will mean a desire for even more guarantees, more choices, and more hedges against risk. Attention will increase to products like annuities with riders to provide long-term care or insurance against a sudden disability. 
For individual companies, the opportunity is to meet changing consumer demands by further developing highly sophisticated risk management tools. Bringing together finance disciplines and actuarial analysis may help us better develop economic measures of risk that will in turn help us underwrite and price better.

This all sounds complicated and can be. But, add one other consumer demand product simplification. If it cannot be explained, it probably cannot be sold. As companies manufacture more sophisticated products, they need to be as sophisticated in helping our distribution networks understand those products - what segment they are built for, and why they are important.

To summarize the product side: for customers, it is all about guarantees, choice, flexibility, safety, and simplicity. For distribution, it is about information. Distributors need information to make the product understandable, and information about the proper market segments.

No group represents all these customer needs as much as the baby boomers. During the next five years, the population in the U.S. between the ages 55 and 64 will grow at a rate of more than 10 times the growth of the population below the age of 55 .

Financially, there is much evidence that this population is not necessarily ready for retirement. The average American nearing retirement has only $\$ 47,000$ in savings and assets, not including real estate. Social Security replaces only 42 per cent of their earnings. Despite this, savings rates in the U.S. have been negative in recent quarters.

A survey done recently on retirement views of consumers yielded a number of interesting points:

- 70 per cent of respondents put saving for retirement a distant third behind shortand medium-term financial spending.

- From 2000 to 2004, a turbulent market period, 59 per cent of Americans felt the economic environment and their personal situation hurt their retirement prospects.

- Almost 40 per cent of the current retirees surveyed were forced to retire before they planned.

Americans seem to understand that they should save more for retirement but just do not.

Here are some interesting facts.

- A quarter of those eligible to participate in a defined contribution 401(k) plan fail to do so.

- For those who participate in $401(\mathrm{k})$ plans, less than 10 per cent contribute the maximum.

- Finally, nearly half of participants in 401(k) plans cash out their savings when they change jobs, incurring heavy tax penalties.

These facts create enormous opportunity for the U.S. life insurance industry. The industry needs to be positioned as being able to provide retirement security.

On a broader industry level, the American Council of Life Insurers (ACLI) launched an extensive effort in 2005 to make the case to regulators and legislators that life insurance products provide long-term retirement security. Surveys of congressional staff representatives in Washington demonstrated the need to build better awareness of the life insurance industry as part of the solution. 
There is no other industry that can provide retirement security like the life insurance industry. We help people accumulate wealth, protect its value over the long haul, convert it into lifetime income, and transfer it to future generations.

ACLI's message is that savings is just part of the retirement security answer. Protection against risks like longevity, long-term care, health-care costs, and management of retirement savings are just as important.

In moving forward, however, the U.S. life insurance industry is not without potential risks.

- The perceptions around annuities continue to be challenging. Some annuity products came under regulatory scrutiny in 2005. States have filed complaints around mis-selling and the appropriateness of some annuity products for the elderly. The insurance industry is taking a proactive approach in responding to these issues.

- Some regulators have been questioning whether tight enough insurable interest laws are in place to protect products from being solely used as investment vehicles for non-interested parties. The industry has worked with legislators and regulators to fight laws that would expand insurable interest and that ultimately could harm the tax-advantaged nature of our products.

- If the life insurance industry is going to continue to meet the challenges from the consumer, and take advantage of the opportunities around retirement security, it will need to be at the forefront of these issues and others.

The turbulent times were difficult to navigate. But the perfect storm did help life insurers focus more keenly on the customer. The industry is now positioned better for the opportunities that lie ahead.

\section{About the Author}

Arthur F. Ryan is chairman and chief executive officer of Prudential Financial, Inc., one of the largest diversified financial institutions in the world. Prior to joining Prudential in December 1994, he had been the president and chief operating officer of Chase Manhattan Bank since 1990. He ran Chase's worldwide retail bank between 1984 and 1990. He was named Chairman of the American Council of Life Insurers (ACLI) in October 2003. He is also co-chair of the New Jersey Performing Arts Center, and a member of the Council on Foreign Relations, on the board of trustees of New York Presbyterian Hospital, Regeneron Pharmaceuticals, Inc., co-chair of the board of Achieve, Inc., an organization created by U.S. governors and business leaders to drive high academic standards for public schools in the U.S., and the Committee to Encourage Corporate Philanthropy. He has a Bachelor of Arts degree in mathematics from Providence College and an honorary Doctor of Science degree from New Jersey Institute of Technology. 